\title{
Effect of Chytriomyces hyalinus on Industrial Wastewater Pre-Treated with Electrocoagulations in a Continuous System
}

\author{
Moisés Tejocote-Pérez ${ }^{1,2}$, Patricia Balderas-Hernández ${ }^{1}$, Carlos Barrera-Díaz ${ }^{1}$, Gabriela Roa-Morales ${ }^{1}$, \\ Victor Bárcena ${ }^{2}$ \\ ${ }^{1}$ Sustainable Chemistry Research Center, State of Mexico Autonomy University and Mexico Autonomy National University \\ (UAEM-UNAM), Toluca, Mexico; ${ }^{2}$ Sciences Faculty, State of Mexico Autonomy University, Cerrillo Campus, Toluca, Mexico. \\ Email: pbalderash@uaemex.mx
}

Received May 26 ${ }^{\text {th }}$, 2012; revised June 29 ${ }^{\text {th }}, 2012$; accepted July $11^{\text {th }}, 2012$

\begin{abstract}
A strain of Chytriomyces hyalinus fungus was applied as a pretreatment on industrial wastewater pollutant using electrocoagulations column of aluminum electrodes in a continuous system. The parameters considered in this experiment include $\mathrm{pH}$, conductivity, color, turbidity, COD (Chemical Oxygen Demand), BOD (Biochemical Oxygen Demand) nitrate, nitrite, and SB (sporangia biomass). Biological and electrocoagulations treatments had the next conditions: Chytriomyces hyalinus solutions 1:10, $60 \mathrm{~min}$ of biological treatment, $50 \mathrm{~mL} / \mathrm{min}$ flow, constant ventilations, $15 \mathrm{~min}$ of electrocoagulations time and 3.4 A of electrical current. Color and turbidity values dropped with a 90\% efficiency (2700 to170 Pt-Co; 120 to10 FAU, respectively), COD 68\% (2100 to $672 \mathrm{mg} / \mathrm{L}$ ), BOD 5 70\% (650 to $195 \mathrm{mg} / \mathrm{L}$ ), nitrate showed an $86 \%$ (3.8 to $0.5 \mathrm{mg} / \mathrm{L}$ ), finally nitrite with a $60 \%$ amount reduction $(1.5$ to $0.6 \mathrm{mg} / \mathrm{L})$. For SB parameter, there was a value rising as same as the treatment time $\left(r^{2}=0.90\right)$ carrying out a $y=94.302^{\mathrm{e} 0.0356 \mathrm{x}}$ model. These results reveal a positive outcome of Chytriomyces hyalinus on industrial wastewater pollutants pre-treated with aluminium electrocoagulations in a continuous system.
\end{abstract}

Keywords: Chytriomyces hyalinus; Electrocoagulations; Industrial; Wastewater

\section{Introduction}

Chytriomyces hyalinus, is a fresh water fungus which degrades organic matter as well as carbohydrates on adverse conditions of water quality [1,2]. It was unknown, until recently, how the proteollytic enzimes that allow the fungus survival in adverse conditions, remove the organic pollutants [3].

Some recordings about fungus aerobic treatments on industrial wastewater presents a $90 \%$ reduction in color, turbidity and phenols amount [4,5], an $80 \%$ in ammonia denitrification [6-8], 50\% Cr (VI) loss [9] also $80 \%$ nitrite and nitrate diminution [2]. Some fungi species such as Aspergillus niger, Aspergillus oryzae, Penicillium corylophilum and Trichoderma viridae can be used as treatments with a 50\% - 80\% efficiency range showing a COD decrease on industrial wastewater [10-12]. Aspergillus oryzae and Rhizopus oligosporus FBP (Fungal Biomass Protein) remove in a $75 \%$ the ammonia amount on industrial wastewater with anaerobic treatments [10].

Based on these traits, Chytriomyces hyalinus can be employed as industrial wastewater biological treatment owing to the fact that degrades soluble and colloidal organic matter. Such treatment consists in the oxidation of the organic matter by bacterial, fungus, protozoa and microalgae consortiums [7,8,13-18]. In this procedure the microorganisms reduce the COD and BOD [19,20].

In many cases, industrial wastewater inhibit the degradation ability of the biological treatments probably due to its effluent character that commonly contains several organic and inorganic pollutants such as phenols, solvents, aromatics, organic matter, metals, dyes, nitrate, nitrite, chloride and salts [6,7,21-24]. In order to solve this problem and increase the efficiency, some authors coupled them with ozono, photocatalysis [4] filtrations [22], Fenton reactions [25,26], chemical coagulants [27, 28] and lastly Fe and Al electrocoagulantion [25,29,30]. Electrocoagulations consists in the formation of metallic hydroxide such as $\mathrm{Fe}(\mathrm{OH})_{2}$ and $\mathrm{Al}(\mathrm{OH})_{3}$ within wastewater by electrodissolution of a soluble anode, this method frequently uses electrodes made of iron $(\mathrm{Fe})$ or aluminum (Al); four phases can be observed: firstly an electrolytic reaction at electrode surfaces, secondly the formation of coagulants in the aqueous phase, then the 
adsorption of soluble or colloidal pollutants on metallic coagulants, and finally the removal by sedimentation or flotation [25,31,32]. The reactions to aluminum electrodes are shown next:

$$
\begin{gathered}
\text { Anode: } \mathrm{Al} \rightarrow \mathrm{Al}(\mathrm{aq})^{3+}+3 \mathrm{e} \\
\text { Cathode: } 3 \mathrm{H}_{2} \mathrm{O}+3 \mathrm{e} \rightarrow 3 / 2 \mathrm{H}_{2}+3 \mathrm{OH}^{-} \\
\text {Anode: } 2 \mathrm{Al}+6 \mathrm{H}_{2} \mathrm{O}+2 \mathrm{OH}^{-} \rightarrow 2 \mathrm{Al}(\mathrm{OH})_{4}^{-}+3 \mathrm{H}_{2}
\end{gathered}
$$

The $\mathrm{Al}(\mathrm{aq})^{3+}$ and $\mathrm{OH}^{-}$ions are generated by an anode (1) and a cathode (2) form several monomeric species previous to $\mathrm{Al}(\mathrm{OH})_{3}$ coagulant (3) which oxides the pollutants and remove them by sedimentation [25], in this process the electrocoagulant $\mathrm{Al}(\mathrm{OH})_{3}$ increases the wastewater pollutant bioavailability to the biological treatments [33].

Lately, the electrochemical treatment of wastewater applies a continuous systems since the procedure increases the wastewater pollutants bioavailability and operate with dynamic treatment plants parameters such as flows, ventilations, hydraulic and organic charge, liquor mix and resident times [14,19,20,34,35].

Due to the bioavailability increment of the industrial wastewater pollutants to biological treatments by electrocoagulations was noticed. The present work evaluates the effect of Chytriomyces hyalinus, whose has not been used as biological treatment for industrial effluents, on industrial wastewater pre-treated with aluminum electrodes in a continuous system.

\section{Materials and Methods}

\subsection{Wastewater Samples}

The industrial wastewater was collected in an industrial treatment plant in México State; $10 \mathrm{~L}$ samples of water were taken prior to the primary clarifiers every month during March-November 2011. The samples were trans- ported in $10 \mathrm{~L}$ plastic containers and stored to $4^{\circ}$ for 24 hrs following the Mexican [36] and International [37] normative.

\subsection{Chytriomyces hyalinus and Electrocoagulations Pretreatment in a Continuous System}

The continuous system applied to evaluate the effects of Chytriomyces hyalinus on electrocoagulation pre-treated industrial wastewater, shown in Figure 1, are based on [35] and [33] systems. The continuous system contains an electrocoagulation column coupled with a Chytriomyces hyalinus aerobic biological reactor.

\subsubsection{Electrocoagulations Reactor}

The electrocoagulation reactor contains four circular aluminum electrodes arranged vertically into an $11 \times 20$ $\mathrm{cm}$ column, the electrodes area is $63.61 \mathrm{~cm}^{2}$ and 0.05 $\mathrm{A} / \mathrm{cm}^{2}$ of current density. The system operates with $1 \mathrm{~L}$ of wastewater volume, a peristaltic pump, constant flow of $50 \mathrm{ml} / \mathrm{min}, 3.4 \mathrm{~A}$ of electrical current, 2.0 psi of ventilations, temperature of $19^{\circ} \mathrm{C}$ and $15 \mathrm{~min}$ of electrochemical pretreatment $[29,33]$.

\subsubsection{Biological Reactor with Chytriomyces hyalinus}

Chytriomyces hyalinus strain was obtained from isolations made to freshwater samples, which were taken from a water body near to Lerma River in Mexico State. Five Chytriomyces hyalinus isolations were made in aseptic conditions using queratine extract medium (KEM) containing $100 \mathrm{~mL}$ of queratine liquid extract, $0.5 \mathrm{~g} \mathrm{NaCl}, 0.2$ g MgCl, 0.05 g glucose and $1000 \mathrm{~mL}$ distilled water. The isolations were incubated up to seven days maintaining $20^{\circ} \mathrm{C}$. The biomass of Chytriomyces hyalinus developed around organic matter flocks in the aseptic medium was

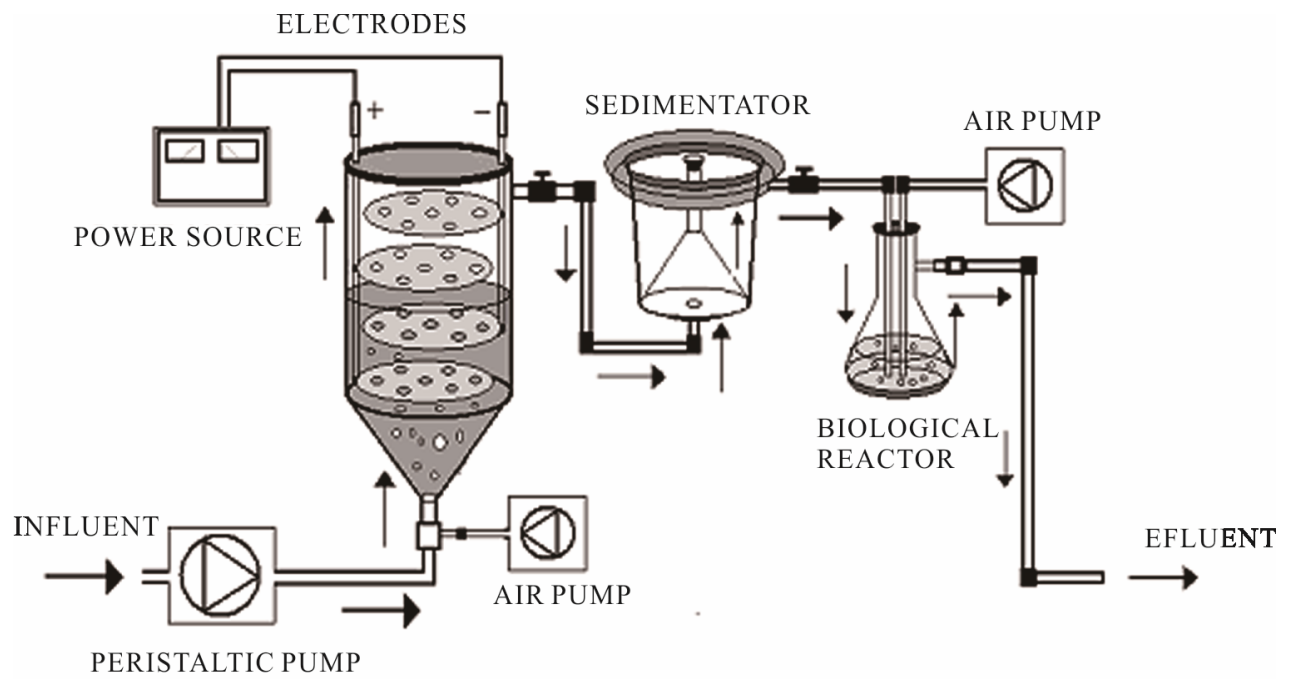

Figure 1. Electrocoagulations-Chytriomyces hyalinus continuous system. 
removed by aseptic vacuum filtrations using filter paper Whatman 4, after that the filtering obtained was inoculated in the biological reactor, described in the Figure 1, with 1:1 concentrations of Chytriomyces hyalinus strains and sterile distilled water, this activated sludge was maintained with 2.0 psi of ventilation during 8 hrs previous to electrocoagulation pre-treatment [24,38].

The electrocoagulation wastewater pre-treatment was conducted to Chytriomyces hyalinus biological reactor by peristaltic pump, Figure 1. The biological reactor was operated with 2.0 psi of ventilations, temperature of $19^{\circ} \mathrm{C}$, and constant flow of $50 \mathrm{ml} / \mathrm{min}$ and $60 \mathrm{~min}$ of biological treatment.

The Chytriomyces hyalinus strain was characterized utilizing an optical microscopic considering the morphology and sporangia biomass (SB) using $\mathrm{KOH} \mathrm{5 \% ,}$ congo red as biological dye and a Leica microscope GME model, the SB in activated sludge and liquor mix was 345 sporangia/mL, this obtained using a Marienfeld Neubauer chamber [39]. The industrial pollutants toxic effects in the biological treatment was evaluated with the $\mathrm{SB}$ (sporangia number/mL of liquor mix) during the biological treatment as well $[24,39]$.

\subsection{Wastewater Characterizations}

Wastewater was characterizes using $\mathrm{pH}$, conductivity, color, turbidity, $\mathrm{BOD}_{5}$, COD, nitrate and nitrite parameters according to the Mexican [36,40,41] and International [37] normative.

\section{4. pH and Conductivity}

Conductivity and $\mathrm{pH}$ were measured directly on wastewater before and after electrochemical and biological treatments using an OAKTON potentiometer 35631-60 model with standard calibration solutions $[37,42]$.

\subsection{Color and Turbidity}

The color and turbidity was evaluated directly on wastewater previous and subsequent to electrochemical and biological treatments applying the standard scale color method of platinum-cobalt (Pt-Co) with a range from 0 to 500 units Pt-Co and the turbidity FAU units' method with a range from 0 to 5000 units. The reads from both methods were made using a Hach spectrophotometer DR/4000U model with 465 and 860 nm wavelength respectively $[37,42]$.

\section{6. $\mathrm{COD}$ and $\mathrm{BOD}_{5}$}

The COD parameter was used to evaluate the amount of organic and inorganic pollutants oxidized by chemical digest with chromic and sulfuric acids in potassium dichromate solutions, the digest was regulated in a ther- moreactor Thermo Elec Corp COD Orion model from $125^{\circ} \mathrm{C}$ to $150^{\circ} \mathrm{C}$, the reaction was maintained during $2 \mathrm{hrs}$, eventually the evaluations were expressed in $\mathrm{mg} / \mathrm{L}$ units by a Hach spectrophotometer DR/4000U model, The $\mathrm{BOD}_{5}$ test was employed to evaluate the oxygen amount needed by microorganisms to oxidize the organic matter during five days of incubation to $20^{\circ} \mathrm{C}$, this test was made using $\mathrm{BOD}_{5}$ Hach bottles kit, a dissolved oxygen meter OAKTON DO 110 model and a incubator VWR Scientific 1535 model $[37,42]$.

\subsection{Nitrate and Nitrite}

The nitrates and nitrites were quantified before and after the electrochemical and biological treatments, such quantifications were made using the Nitraver ${ }^{\circledR} X$ and Nitriver $^{\circledR} 3$ methods of Hach besides the values were determinate by a spectrophotometer Hach DR/4000U. These quantifications were made according to the normative $[37,42]$.

\subsection{UV-Visible Spectrophotometer}

Some water samples previous and behind electrochemical-biological treatments were analyzed by spectrophotometer UV-visible Perkin Elmer Lambda 25 model (200 $900 \mathrm{~nm}$ ) this technique is necessary to identify the behavior of some organic pollutants considering their absorption properties [32].

\section{Results and Discussions}

\subsection{Parameters}

The $\mathrm{pH}$, conductivity, color, turbidity, COD, $\mathrm{BOD}_{5}$, nitrate and nitrite values of industrial wastewater before and after continuous coupled systems are shown in Table 1.

\subsection{1. pH and Conductivity}

The $\mathrm{pH}$ value intensified from $7.45 \pm 0.84$ to $8.45 \pm 0.50$ in consequence of continuous system, this behavior is shown in Figure 2(a). The $\mathrm{pH}$ boosted as a result of the $\mathrm{OH}^{-}$radicals production on cathode surfaces from aluminum electrodes into the electrochemical column and the $\mathrm{OH}^{-}$radicals electrodisolution in the aluminum hydroxide $\mathrm{Al}(\mathrm{OH})_{3}$ reactions. The $\mathrm{pH}$ values before and after the treatment corresponding to common industrial wastewater with 7.0 and 9.0 values is a beneficial condition to be applied in the electrochemical and biological treatments [33].

The Figure 2(b) divulge the conductivity abate form $6.7 \pm 0.44$ to $4.57 \pm 0.30 \mathrm{mS}$, this tendency is caused by $\mathrm{Cl}^{-}$as well as chlorides salts consumption in electrocoagularion redox reactions [25,29,32].

The conductivity values indicate a beneficial condition 
applying only 15 min electrochemical pulse in the coupled treatment. Furthermore there is a gain in the pollutants bioavailability to Chytriomyces hyalinus $[14,19$, 20,33-35].

\subsubsection{Color and Turbidity}

The color displays high values in wastewater samples earlier from the coupled treatment; additionally it was produced by dissolved organic matter from chemical and food industries effluents [29]. Literature points Aspergillus and Penicillium as color discharge up to $90 \%$ in coupled systems, for these experiment Figure 2(c) shows a 93\% color removal using Chytriomyces hyalinus, a $50 \%$ more efficient than conventional activated sludge
$[4,5,10,30,32]$. It is to say that electrochemical pretreatment enhance the industrial pollutant bioavailability to Chytriomyces hyalinus.

As perceived in Figure 2(c), the turbidity had a similar behavior pointing that the values diminish from 120 to 10 FAU with 91\% efficiency after using Chytriomyces hyalinus electrocoagulation system. Thus only with Chytriomyces hyalinus the efficiency rate was higher than $60 \%$ reported to conventional biological treatment for activated sludge [4,5,10,30,32].

Both, color and turbidity parameters register a shrinks after a 15-min of biological treatment, meaning that the pollutant bioavailability improves in coupled condition of continuous system.

Table 1. Values of $\mathbf{p H}$, conductivity, color, turbidity, $\mathrm{COD}, \mathrm{BOD}_{5}$, nitrate and nitrites before and after the electrocoagulations-Chytriomyces hyalinus treatment.

\begin{tabular}{ccccccccc}
\hline & pH & $\begin{array}{c}\text { Conductivity } \\
(\mathbf{m S})\end{array}$ & $\begin{array}{c}\text { Color } \\
(\mathbf{P t}-\mathbf{C o})\end{array}$ & $\begin{array}{c}\text { Turbidity } \\
\mathbf{( F A U )}\end{array}$ & $\begin{array}{c}\text { COD } \\
(\mathbf{m g} / \mathbf{L})\end{array}$ & $\begin{array}{c}\text { BOD } \\
(\mathbf{m g} / \mathbf{L})\end{array}$ & $\begin{array}{c}\text { Nitrate } \\
(\mathbf{m g} / \mathbf{L})\end{array}$ & $\begin{array}{c}\text { Nitrite } \\
(\mathbf{m g} / \mathbf{L})\end{array}$ \\
\hline Before & $\mathbf{7 . 4 5} \pm 0.84$ & $\mathbf{6 . 7} \pm 0.44$ & $\mathbf{2 7 0 0} \pm 51.43$ & $\mathbf{1 2 0} \pm 19.30$ & $\mathbf{2 1 0 0} \pm 42.86$ & $\mathbf{6 5 0} \pm 23.12$ & $\mathbf{3 . 8} \pm 0.41$ & $\mathbf{1 . 5} \pm 0.22$ \\
After & $\mathbf{8 . 4 5} \pm 0.50$ & $\mathbf{4 . 5 7} \pm 0.30$ & $\mathbf{1 7 0} \pm 2.0$ & $\mathbf{1 0} \pm 1.2$ & $\mathbf{6 7 2} \pm 10.6$ & $\mathbf{1 9 5} \pm 4.1$ & $\mathbf{0 . 5} \pm 0.20$ & $\mathbf{0 . 6} \pm 0.10$ \\
$\%$ & & & $\mathbf{9 3}$ & $\mathbf{9 1}$ & $\mathbf{6 8}$ & $\mathbf{7 0}$ & $\mathbf{8 6}$ & $\mathbf{6 0}$ \\
\hline
\end{tabular}

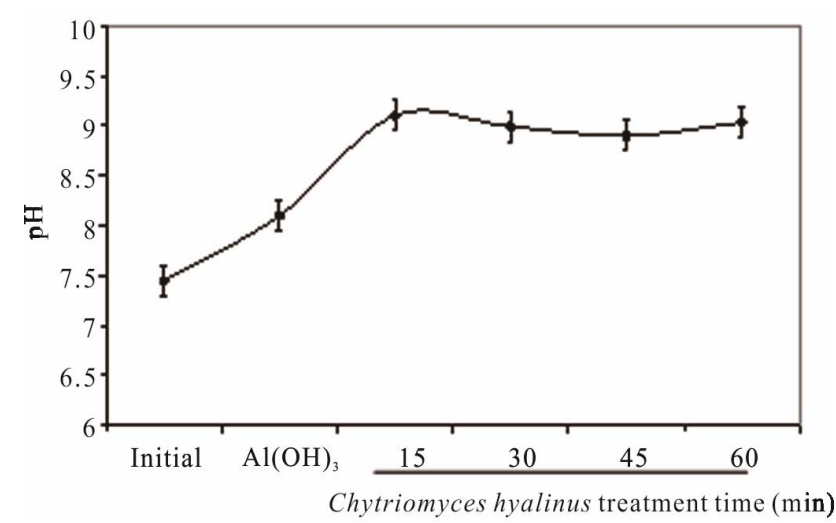

(a)

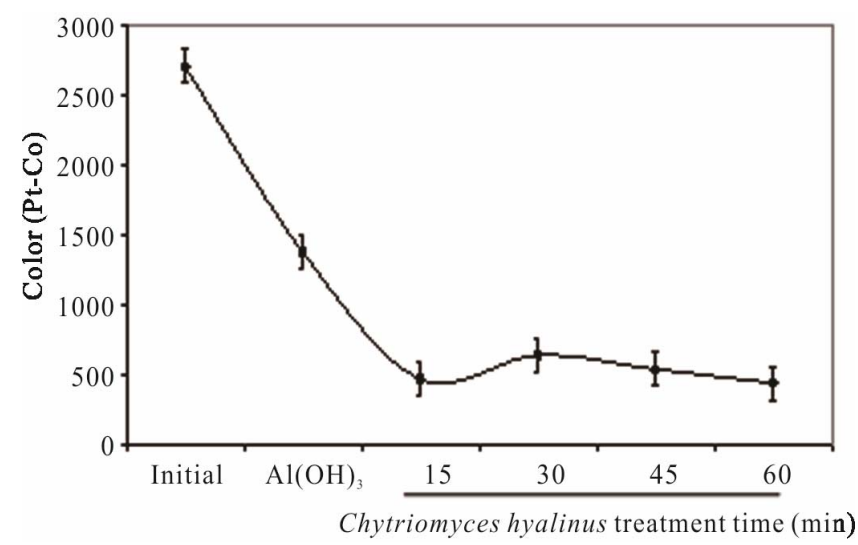

(c)

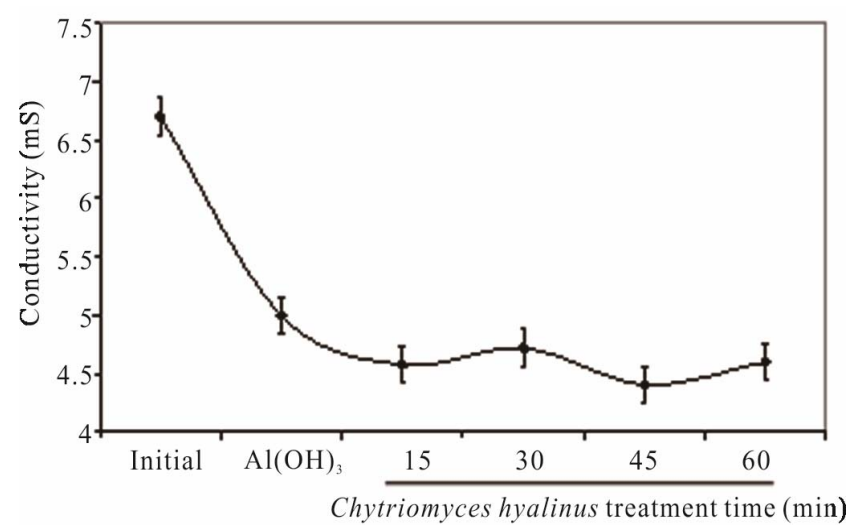

(b)

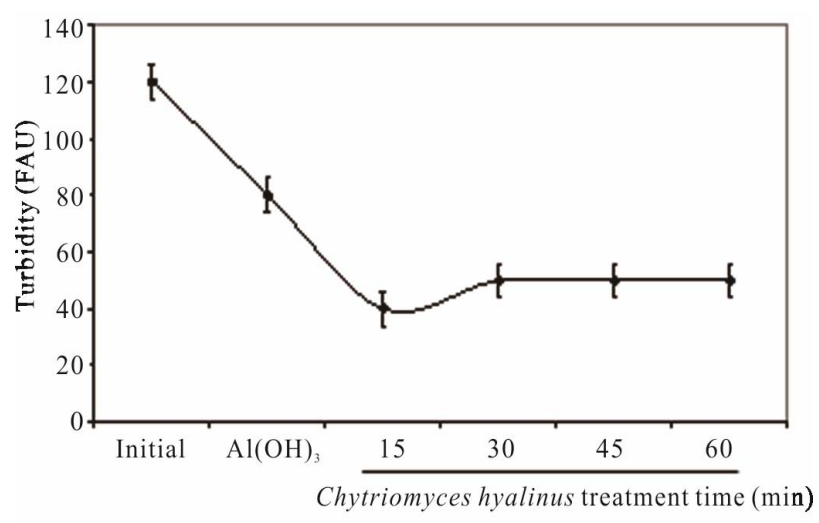

(d)

Figure 2. (a) pH; (b) Conductivity; (c) Color and (d) Turbidity during the electrochemical-Chytriomyces hyalinus treatment. 


\subsection{3. $\mathrm{COD}$ and $\mathrm{BOD}_{5}$}

The COD and $\mathrm{BOD}_{5}$ values in Figure 3, show a pollutant removal efficiency declining, $68 \%$ and $70 \%$, respectively $[8,11,12]$. Such fact indicates that Aspergillus niger, Aspergillus oryzae, Penicillium corylophilum and Trichoderma viridae tends to contract in a $50 \% \mathrm{COD}$ and $\mathrm{BOD}_{5}$ levels, exposing a greater reaction rather than the one presented by reference $[8,11,12]$.

The COD and $\mathrm{BOD}_{5}$ results reveal three important points. In first place, Aspergillus, Penicillium and Trichoderma strains share a pluricellular organization while Chytriomyces hyalinus posses an unicellular level, such biological advantage rises the biomass presence like the resident time during the treatment, whereas this datum represent an inconvenience for Chytriomyces hyalinus. Moreover the COD and $\mathrm{BOD}_{5}$ upshots presents the same efficiency rate; even using a lower resident time $[8,11$, 12].

In second place, $\mathrm{COD}$ and $\mathrm{BOD}_{5}$ parameters can now be considered as a new contribution to biological treatment of activated sludge since the values were lessen by using fungus strains only, while the conventional treatments of activated sludge use several microorganisms

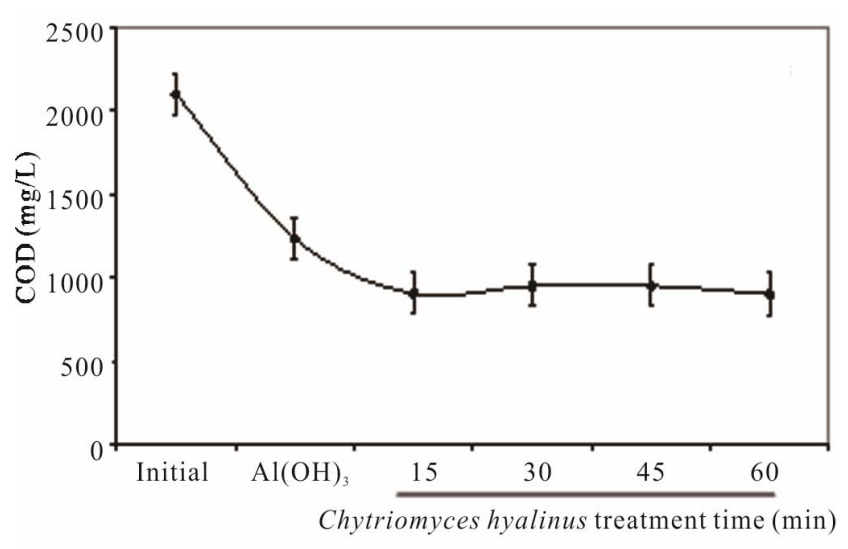

(a)

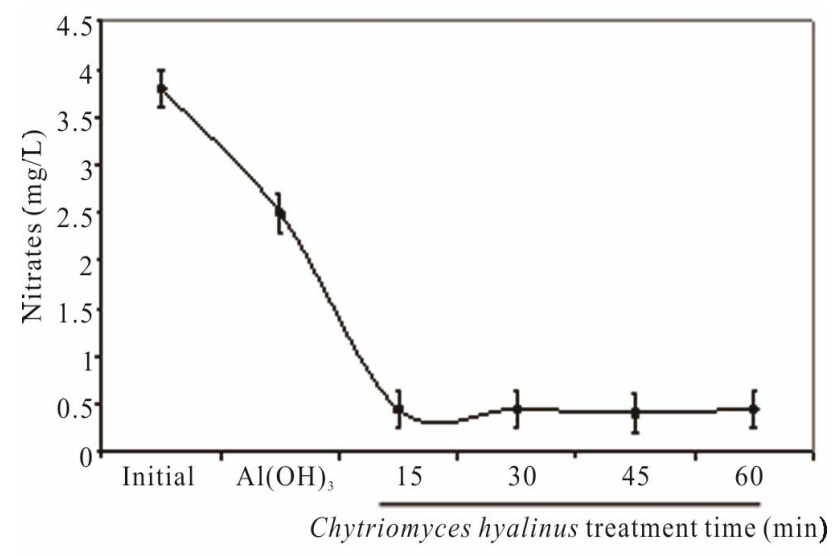

(c) consortiums [7,8,13-18].

In third place, it stresses the coupled continuous system role in the removal efficiency owing to the electrocoagulation conditions that raises the bioavailability of industrial wastewater pollutants to Chytriomyces hyalinus. [14,19,20,25,29,33-35].

Making this study the first report of industrial pretreated wastewater by electrocoagulation coupled with Chytriomyces hyalinus as a biological system.

\subsubsection{Nitrate and Nitrite}

Nitrates $\left(\mathrm{NO}_{3}^{-}\right)$and nitrites $\left(\mathrm{NO}_{2}^{-}\right)$dwindled subsequent to the biological treatment from 3.8 to $0.5 \mathrm{mg} / \mathrm{L}$ and from 1.5 to $0.6 \mathrm{mg} / \mathrm{L}$ with an effectiveness of $86 \%$ and $60 \%$ respectively. Such behavior is displayed in Figure 3.

Nitrates were more affected than nitrites because its chemical nitrogen trait, having as a result a higher biological assimilation thanks to aquatic microorganisms [2,6-8].

These nitrogenous compounds, industrial pollutants type, are presented naturally in the experimental effluent, therefore it is important to make a continuous revision

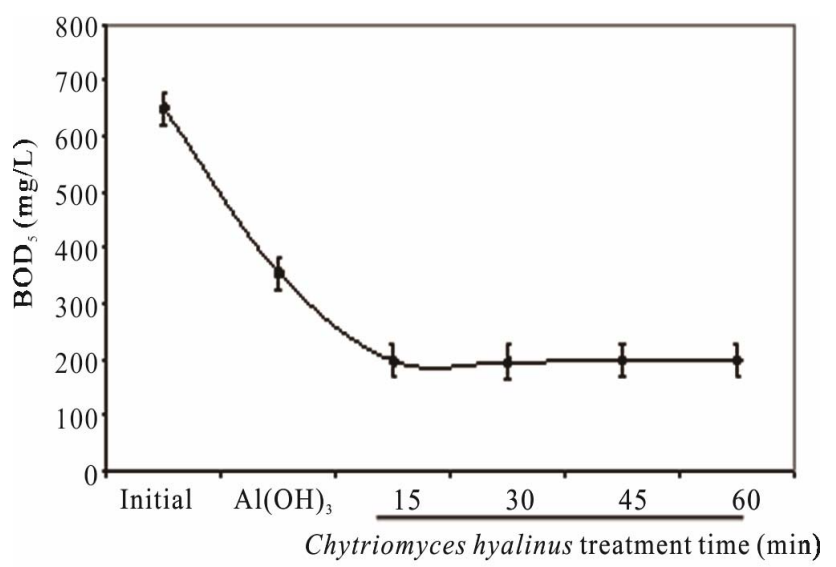

(b)

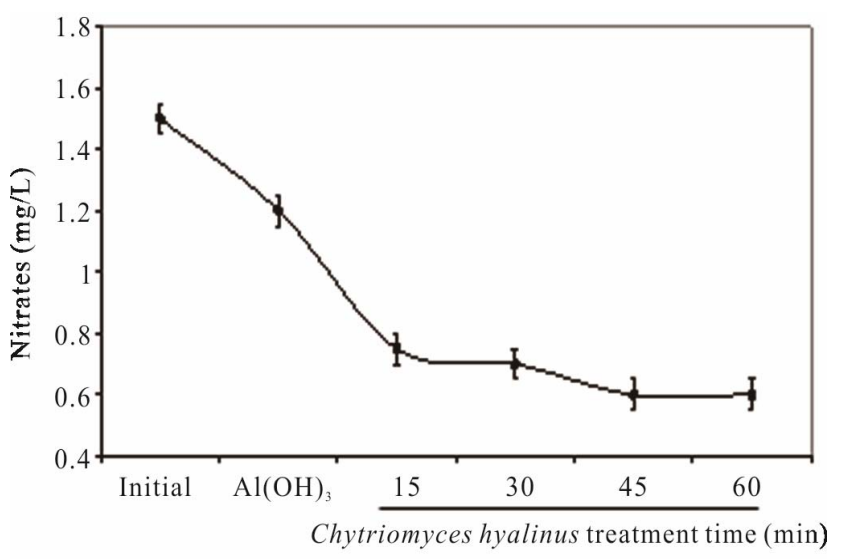

(d)

Figure 3. (a) COD, (b) $\mathrm{BOD}_{5}$, (c) nitrates and (d) nitrites during the electrochemical-Chytriomyces hyalinus treatment. 
during the coupled treatment because the pollutant removal tendency in the continuous system can manifest. The nitrogenous compounds removal grew when they were oxidize, nitrates into nitrites by electrocoagulation treatments $[25,31,32]$. The nitrates amount and removal efficiency were higher than nitrites due to the reduction from nitrites to nitrates at the electrochemical reactor besides the quickly assimilation by Chytriomyces hyalinus in the biological reactor.

This reduction is an evidence of Chytriomyces hyalinus active metabolism in addition to water denitrification in aerobic conditions as its natural ability [2-4].

Similar industrial pollutant denitrification greater than $50 \%$ were reported by $[6-8,10]$ with Aspergillus oryzae and Rhizopus oligosporus.

\subsection{Sporangia Biomass (SB)}

Figure 4 shows Chytriomyces hyalinus SB concentrations on a 60-min session of biological treatment. The biomass suffered an increment as a result of 30 min by the time sporangia amount increased. The SB tendency indicates that Chytriomyces hyalinus is capable of resisting the pollutant conditions in the liquor mix, noticed by an exponential growth $y=94.302^{\mathrm{e} 0.0356 \mathrm{x}}[10,24,39]$.

SB value ascended when $\mathrm{COD}$ and $\mathrm{BOD}_{5}$ values decrease, this reaction denotes that pollutants bioavailability to Chytriomyces hyalinus were modified within a 15min of electrochemical treatment, hence the toxic effect of industrial wastewater on biological treatment was reduced; opposite to the frequent problem in bio-logical treatment inhibitions [6,7,21-24].

Samanthi and Chandralata (2009) report an optimal growth for Chytriomyces hyalinus in some aquatic systems, showing $\mathrm{pH}$ values from 6.8 to 8.5, electrochemi$\mathrm{cal}$ and biological conditions in the treatment were kept into these $\mathrm{pH}$ values, consequently the pollutants removal suffered an increment.

The sludge amount after biological treatments with Chytriomyces hyalinus was $2 \mathrm{~g} / \mathrm{L}$, within normal range from 0.5 to $5 \mathrm{~g} / \mathrm{L}$ was reported in laboratory level experiments [21-24].

\subsection{UV-Visible Spectrophotometer Characterizations}

A pollutant decrement followed by electrocoagolutions Chytriomyces hyalinus system treatment can be observed in Figure 5. The absorbance indicates a spectral reduction with a $60 \%$ efficiency, showing an absorbance result of 400, 475 and $625 \mathrm{~nm}$ corresponding to phenols, solvents, aromatic and organic matter; similar wastewater spectra cases have been reported [29,32,33]. The current tendency was consistent with $\mathrm{COD}$ and $\mathrm{BOD}_{5}$ results.

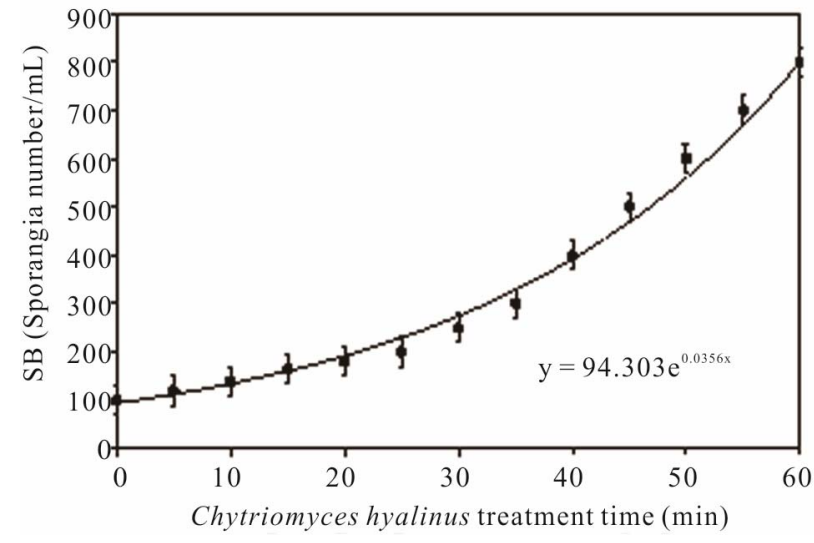

Figure 4. Sporangia biomass and Chytridium hyalinus treatment time.

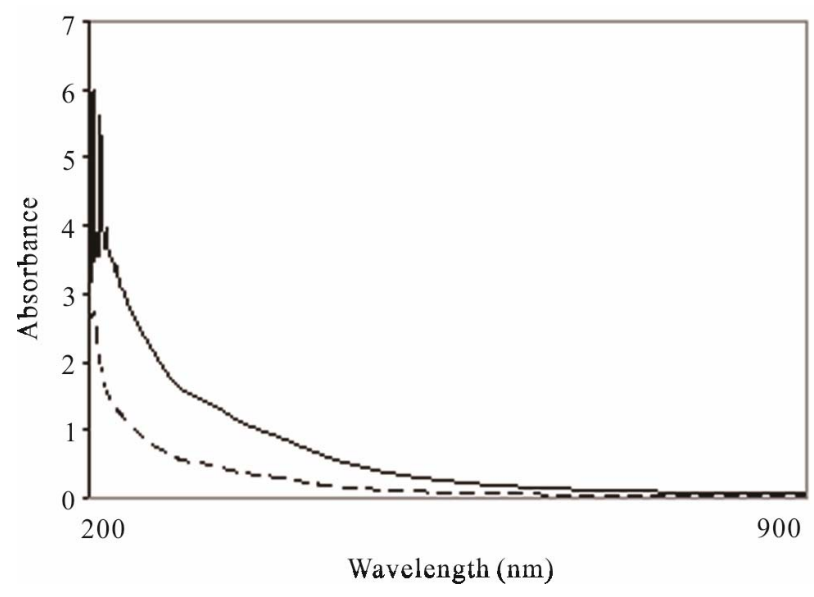

Figure 5. UV visible characterizations of industrial wastewater before (-) and after (----) electrocoagulations-Chytriomyces hyalinus treatment.

\section{Conclusion}

All in all the Chytryomyces hyalinus effect on industrial pre-treated wastewater by electrocoagulations in a continuous system had a positive efficiency on pollutants removal. The electrochemical pulse with aluminum electrodes extends the pollutants bioavailability to Chytryomyces hyalinus. Color and turbidity exhibited a reduction with $90 \%$ efficiency, COD $62 \%$, BOD $_{5} 69 \%$, nitrate $86 \%$ and nitrite $60 \%$. Chytryomyces hyalinus sporangial bio-mass (SB) heightens exponentially attending to a $\mathrm{y}=$ $94.302 \mathrm{e}^{0.0356 \mathrm{x}}$ model, additionally increases when pollutant concentration fall, so as $\mathrm{COD}, \mathrm{BOD}_{5}$, nitrate and nitrite values. Finally the pollutants removed exposes a UV-visible spectra corresponding to organic pollutants.

\section{Acknowledgements}

The authors wish to acknowledge CONACYT and Universidad Autónoma del Estado de México for the support given to this project 2794/2010-2011. 


\section{REFERENCES}

[1] S. Golubic, G. Radtke and T. Le, "Campion-Alsumard, Endolithic Fungi in Marine Ecosystems,” Trends in Microbiology, Vol. 13, No. 5, 2005, pp. 229-234. doi:10.1016/j.tim.2005.03.007

[2] J. Sumathi and R. Chandralata, “Anaerobic Denitrifications in Fungi from the Coastal Marine Sediments off Goa, India,” Mycological Research, Vol. 113, No. 1, 2009, pp. 100-109. doi:10.1016/j.mycres.2008.08.009

[3] G. Hageskal, N. Lima and I. Skaar, "The Study of Fungi in Drinking Water," Mycological Research, Vol. 113, No. 2, 2009, pp. 165-172. doi:10.1016/j.mycres.2008.10.002

[4] M. Barreto-Rodríguez, J. V. Souza, S. E. Silva, T. F. Silva and C. B. T. Pavia, "Combined Photocatalytic and Fungal Processes for the Treatment of Nitrocellulose Industry Wastewater," Journal of Hazardous Materials, Vol. 161, No. 2-3, 2009, pp. 1569-1573. doi:10.1016/j.jhazmat.2008.05.012

[5] T. Dalsgaard, D. E. Canfield, J. Petersen, B. Thamdrup and J. Acuña-González, "N2 Productions by the Anammox Reactions in the Anoxic Water Column of Golfo Dulce, Costa Rica,” Nature, 422, No. 6932, 2003, pp. 606-608. doi:10.1038/nature01526

[6] G. Buttiglieri, F. Malpei, E. Daverio, M. Melchiori, H. Nieman and J. Ligthart, "Denitrification of Drinking Water Sources by Advanced Biological Treatment Using a Membrane Bioreactor,” Desalination, Vol. 178, No. 1-3, 2005, pp. 211-218. doi:10.1016/j.desal.2004.11.038

[7] Y. T. Ahn, S. T. Kang, S. R. Chae, C. Y. Lee, B. U. Bae and H. S. Shin, "Simultaneous High-Strength Organic and Nitrogen Removal with Combined Anaerobic Upflow Bed Filter and Aerobic Membrane Bioreactor,” Desalination, Vol. 202, No. 1-3, 2007, pp. 114-121. doi:10.1016/j.desal.2005.12.046

[8] T. R. Thomsen, Y. Kong and P. H. Nielsen, "Ecophysiology of Abundant Denitrifying Bacteria In-Activated Sludge,” Microbiology Ecological, Vol. 60, No. 3, 2007, pp. 370-382. doi:10.1111/j.1574-6941.2007.00309.x

[9] K. Rajender, R. N. Bishnoi and K. G. Bishnoi, "Biosorption of Chromium Cr (VI) from Aqueous Solutions and Electroplating Wastewater Using Fungal Biomass,” Chemical Engineering Journal, Vol. 135, No. 3, 2008, pp. 202209.

[10] J. Bo, X. Q. Yan, Q. Yu and J. H. Van Leeuwen, “A Comprehensive Pilot Plant System for Fungal Biomass Protein Productions and Wastewater Reclamation," Advances in Environmental Research, Vol. 6, No. 2, 2002, pp. 179-189. doi:10.1016/S1093-0191(01)00049-1

[11] A. Zahangir and A. Fakhru'l-Razi, "Enhanced Settlebility and Dewaterability of Fungal Treated Do-Mestic Wastewater Sludge by Liquid State Bioconversion Process,” Water Research, Vol. 37, No. 5, 2003, pp. 1118-1124. doi:10.1016/S0043-1354(02)00452-9

[12] Y. Z. Zhang, B. Jin, H. Z. Bai and Y. X. Wang, "Production of Fungal Biomass Protein Using Microfungi from Winery Wastewater Treatment,” Bioresource Technology, Vol. 99, No. 9, 2008, pp. 3871-3876. doi:10.1016/j.biortech.2006.10.047
[13] E. Liwarska-Bizukojc, “Application of Image Analysis Techniques in Activated Sludge Wastewater Treatment Processes,” Biotechnology Letters, Vol. 27, No. 19, 2005, pp. 1427-1433. doi:10.1007/s10529-005-1303-2

[14] D. K. Sharma, H. S. Saini, M. Singh, S. S. Chimni and B. S. Chadha, "Biological Treatment of Textile Dye Acid Violet-17 by Bacterial Consortium in an Up-Flow Immobilized Cell Bioreactor,” Letters in Applied Microbiology, Vol. 38, No. 5, 2004, pp. 345-350. doi:10.1111/j.1472-765X.2004.01500.X

[15] C. J. Van der Gast, A. S. Whiteley and I. P. Thompson, "Temporal Dynamics and Degradation Activity of a Bacterial Inoculum for Treating Waste Metal-Working Fluid," Environmental Microbiology, Vol. 6, No. 3, 2004, pp. 254-263. doi:10.1111/j.1462-2920.2004.00566.x

[16] C. Kragelund, C. Levantesi, A. Borger, K. Thelen, D. Eikelboom, V. Tandoi, Y. Kong, J. Van der Waarde, J. Krooneman, S. Rossetti and T. R. ThomsenNielsen, "Identity, Abundance and Ecophysiology of Filamentous Chloroflexi Species Present in Activated Sludge Treatment Plants," Microbiological Ecology, Vol. 59, No. 3, 2007, pp. 671-682. doi:10.1111/j.1574-6941.2006.00251.x

[17] S. Rossetti, M. Tomei, P. Nielsen and V. Tandoi, “Microthrix parvicella, a Filamentous Bacterium Causing Bulking and Foaming in Activated Sludge Sys-Tems: A Review of Current Knowledge,” Microbiology Review, Vol. 29, No. 1, 2005, pp. 49-64.

[18] V. L. Barbosa, S. D. Atkins, V. P. Barbosa, J. E. BurGess and R. M. Stuetz, "Characterization of Thiobacillus thioparus Isolated from an Activated Sludge Bioreactor Used for Hydrogen Sulfide Treatment," Journal of Applied Microbiology, Vol. 101, No. 6, 2006, pp. 1269-1281. doi:10.1111/j.1365-2672.2006.03032.x

[19] F. Fatone, D. Bolzonella, P. Battistoni and F. Cecchi, "Removal of Nutrients and Micropollutants Treating Low Loaded Wastewaters in a Membrane Bioreactor Operating the Automatic Alternate-Cycles Process,” Desalination, Vol. 183, No. 1-3, 2005, pp. 395-405. doi:10.1016/j.desal.2005.02.055

[20] J. D. Jang, J. P. Barford, A. Lindawati and R. Renneberg, "Application of Biochemical Oxygen Demand (BOD) Biosensor for Optimization of Biological Carbon and Nitrogen Removal from Synthetic Wastewater in a Sequencing Batch Reactor System,” Biosensor and Bioelectrode, Vol. 19, No. 8, 2004, pp. 805-812. doi:10.1016/j.bios.2003.08.009

[21] C. Della Rocca, V. Belgiorno and S. Meric, "Over-View of In-Situ Applicable Nitrate Removal Processes,” Desalination, Vol. 204, No. 1-3, 2007, pp. 46-62. doi:10.1016/j.desal.2006.04.023

[22] Y. H. Kim, E. D. Hwang, W. S. Shin, J. H. Choi, T. W. Ha and S. J. Choi, "Treatments of Stainless Steel Wastewater Containing a High Concentration of Nitrate Using Reverse Osmosis and Nanomembranes," Desalination, Vol. 202, No. 1-3, 2007, pp. 286-292. doi:10.1016/j.desal.2005.12.066

[23] M. Milovanovic, "Water Quality Assesment and DeTermination of Pollution Sources along the Axios/Vardar 
River, Southeastern Europe,” Desalination, Vol. 213, No. 1-3, 2007, pp. 159-173. doi:10.1016/j.desal.2006.06.022

[24] M. Ricart, E. Guasch, M. Alberch, D. Berceló, C. Bonnineau, A. Geiszinger, M. La Farré, J. Ferrer, F. Ricciardi, A. Romaní, S. Morín, L. Proia, L. Sala, D. Sureda and S. Sabater, "Triclosan Persistence through Wastewater Treated Plants and Its Potential Toxic Effects on Rever Biofilms," Aquatic Toxicology, Vol. 100, No. 4, 2010, pp. 346-353. doi:10.1016/j.aquatox.2010.08.010

[25] P. Cañizares, R. Paz, C. Sáez and M. A. Rodrigo, “Cost of the Electrochemical Oxidation of Wastewaters: A Comparison with Ozonations and Fenton Oxidation Processes,” Journal of Environment Management, Vol. 90, No. 1, 2009, pp. 410-420. doi:10.1016/j.jenvman.2007.10.010

[26] K. V. Padoley, S. N. Mudliar, S. K. Banerjee, S. C. Deshmukh and R. A. Pandey, "Fenton Oxidation: A Pretreatment Option for Improved Biological Treatment of Pyridine and 3-Cyanopyridine Plant Wastewater," Chemical Engineering Journal, Vol. 166, No. 1, 2011, pp. 1-9. doi:10.1016/j.cej.2010.06.041

[27] O. Amuda and I. Amoo, "Coagulation/Flocculation Process and Sludge 5 Conditioning in Beverage Industrial Wastewater Treatment,” Journal of Hazardous Materials, Vol. 141, No. 3, 2007, pp. 778-783. doi:10.1016/j.jhazmat.2006.07.044

[28] R. Braz, A. Pirra, M. Lucas and J. Peres, “Combinations of Long Term Aerated Storage and Chemical Coagulations/Flocculations to Winery Wastewater Treatment," Desalinations, Vol. 263, No. 1-3, 2010, pp. 226-232. doi:10.1016/j.desal.2010.06.063

[29] C. Barrera-Díaz, G. Roa-Morales, L. Avila-Cordoba, T. Pavon-Silva and B. Bilyeu, "Electrochemical Treatment Applied to Food-Processing Wastewater Treatment," Industrial Engineering Chemical Research, Vol. 45, No. 1, 2006, pp. 34-38. doi:10.1021/ie050594k

[30] M. Panizza and G. Cerisola, "Elechtrochemical Oxidation as a Final Treatment of Synthetic Tannery Wastewater," Environment Science Technology, Vol. 38, No. 20, 2004, pp. 5470-5475. doi:10.1021/es049730n

[31] D. Rajkumar and K. Palanivelu, "Electrochemical Degradations of Cresols for Wastewater Treatment," Industrial Engineering Chemical Research, Vol. 42, No. 9, 2003, pp. 1833-1839. doi:10.1021/ie020759e

[32] G. Roa-Morales, E. Campos-Medina, E. Aguilera-Cotero, B. Bilyeu and C. Barrera, "Aluminium Electrocuagulation with Peroxide Applied to Wastewater from Pasta and Cookie Processing," Separations and Purifications Technology, Vol. 54, No. 1, 2006. pp. 124-129.

\section{doi:10.1016/j.seppur.2006.08.025}

[33] M. Tejocote-Pérez, P. Balderas-Hernández, C. E BarreraDíaz, G. Morales and R. Natividad-Rangel, “Treatment of Industrial Effluents by a Continuous System: Electrocoagulation-Activated Sludge," Bioresource Technology, Vol. 101, No. 20, 2010, pp. 7761-7766.

doi:10.1016/j.biortech.2010.05.027

[34] D. W. Graham and V. H. Smith, "Designed Ecosystem Services: Application of Ecological Principles in Wastewater Treatment Engineering," Fronts in Ecology and the Environment, Vol. 2, No. 4, 2004, pp. 199-206. doi:10.1890/1540-9295(2004)002[0199:DESAOE]2.0.C $\mathrm{O} ; 2$

[35] N. N. Sang, S. Soda, K. Sei and M. Ike, "Effect of Aereation on Stabilization of Organic Solid Waste and Microbial Populations Dynamics in Lab-Scale Landfill Bioreactors," Journal of Bioscience and Bioengineering, Vol. 106, No. 5, 2008, pp. 425-432. doi:10.1263/jbb.106.425

[36] NMX-AA-028-SCFI, "Water Analysis-Determination for Biochemical Oxygen Demand $\left(\mathrm{BOD}_{5}\right)$ in Natural, Wastewaters and Wastewaters Treated-Test Method," Diario Oficial de la Federación, México, 2005.

[37] American Public Health Association, American Water Works Association, Water Environment Federation, "Standard Methods for the Examination of Water and Wastewater,” Washington DC, Denver, Alexandria, 2005.

[38] T. T. More, S. Yan, R. D. Tyagi and R. Y. Surampalli, "Potential Use of Filamentous Fungi for Wastewater Sludge Treatment," Bioresource Technology, Vol. 101, No. 20, 2010, pp. 7691-7700. doi:10.1016/j.biortech.2010.05.033

[39] M. V. Garcia, A. C. Monteiro, M. J. P. Szabo, N. Prette and G. H. Bechara, "Mechanism of Infection and Colonization of Rhiphicephalus Sanguineus Eggs by Metarhizium anisopliae as Revealed by Scanning Electron Microscopy and Histopathology,” Brazilian Journal of Microbiology, Vol. 36, No. 3, 2005, pp. 368-372. doi:10.1590/S1517-83822005000400012

[40] NMX-AA-030-SCFI, "Water Analysis-Determination for Chemical Oxygen Demand (COD) in Natural, Wastewaters and Wastewaters Treated-Test Method,” Diario Oficial de la Federación, México, 2001.

[41] NMX-AA-034-SCFI, "Water Analysis-Determination of Salts and Solids Dissolved in Natural, Wastewaters and Wastewaters Treated-Test Method,” Diario Oficial de la Federación, México, 2001.

[42] HACH, "Water Analysis Manual,” HACH Co., Loveland, 2008. 